\title{
Torrefaction as a Process for Biomass Conversion into Biocoal
}

\author{
BOJAN R. CRNOGAĆA, Eurosalon fabrika, Belgrade
}

Professional paper

UDC: 662.63

DOI: 10.5937/tehnika1703323C

\begin{abstract}
Torrefaction is a thermo-chemical treatment of biomass carried out within a temperature range from $250{ }^{\circ} \mathrm{C}$ to $300^{\circ} \mathrm{C}$, in an inert atmosphere. The process can be described as a mild form of pyrolysis. During the torrefaction process, biomass undergoes a slight breakdown and physical water (moisture) contained in biomass as well as superfluous volatiles are released while the biopolymers (cellulose, hemicelluloses and lignin) partly decompose giving off various types of volatiles. In the course of the process, the properties of biomass change and result in much better quality of fuel combustion and gassification. The final product is the remaining solid, dry, brittle, blackened material that is referred to as torrefied biomass (bio-coal) and which is more resistant to biological degradation, self-ignition and physical decomposition. This paper presents a comprehensive review of torrefaction including both advantages and disadvantages of the torrefaction process.
\end{abstract}

Key words: biomass, torrefaction, pyrolysis, biopolymer

\section{INTRODUCTION}

Renewable sources of energy (sunlight, water, wind, biomass, geothermal heat and waves...) are inexhaustible natural resources of energy which are naturally replenished on a human timescale, entirely or partly. These sources of energy are exploited to generate electrical, thermal and mechanical energy and their significant sustainable feature is that they are renewable contrary to the fossil fuels with finite resources. The energy production from renewable sources (except biomass) does not lead to the emission of carbon dioxide and any other pollutants; biomass is considered to have less impact to the global cycle of carbon than fossil fuels or even to have a neutral impact in the case of waste biomass. In a wide range of different sources of energy, biomass is considered only renewable energy resource based on sustainable carbon. There are a number of scenarios predicting important role of biomass in the energy future [1]. Apart of direct combustion of biomass, biomass can be converted into biofuels using thermochemical, biochemical or chemical conversion. Amongst different methods of thermochemical conversion processes, gasification is the most promising one. Cur

Author's address: Bojan Crnogaća, Eurosalon fabrika, Belgrade, Dunavska bb

e-mail: bojan.crnogaca@eurosalon-fabrika.com

Paper received: 17.02.2017

Paper accepted: 17.05.2017. rently, biomass ranks as the fourth largest energy source in the world after sun, wind and water.

\section{TORREFACTION}

The word torrefaction is derived from the French verb »torrefier «, meaning to roast and is chiefly used to describe the process of roasting coffee beans. In terms of its current application, torrefaction is a thermal treatment process carried out in an inert atmosphere within a narrow temperature range from 250 to $300{ }^{\circ} \mathrm{C}$ [2]. The above mentioned process presents a mild form of biomass pyrolysis that is the thermal decomposition of biomass complex chemical composition at high temperatures resulting in simpler components. The final product of torrefaction is biocoal (also known as biochar). The treatment is an innovative process for production of raw materials suitable for energy production [3]. Amongst the key advantages of this alternative fuel, compared to direct utilisation of biomass as unfiltered fuel, are better properties of energy (higher content of energy) and favorable logistic properties. The objective of torrefaction is to create the fuel that would be used for production of heat and electrical energy [4].

The temperature applied in the treatment is lower than in other thermochemical techniques and it means that it requires less energy. The content of the biocoal energy is much higher than of the untreated biomass and thus a smaller quantity of biocoal can generate the same quantity of energy as untreated biomass. This 
also contributes to reduction of carbon dioxide $\left(\mathrm{CO}_{2}\right)$ emission per unit of the generated energy.

This alternative fuel has some key advantages over direct utilization of biomass as a fuel. Untreated biomass can be stored only for a certain period due to growth of microorganisms and the resulting biomass decay, which is not the case with carbonized biomass (biocoal). Biocoal can be used as fuel in almost every kind of coal-fired power plants. The content of energy per unit of quantity is higher for biocoal than for biomass and it means that biocoal produces more energy with the same quantity of biomass. Smaller quantities of biocoal are needed to produce the same quantity of energy and therefore they require less space for storage and transport. Figure 1 shows final pelleted product of biomass resulting from the torrefaction process.

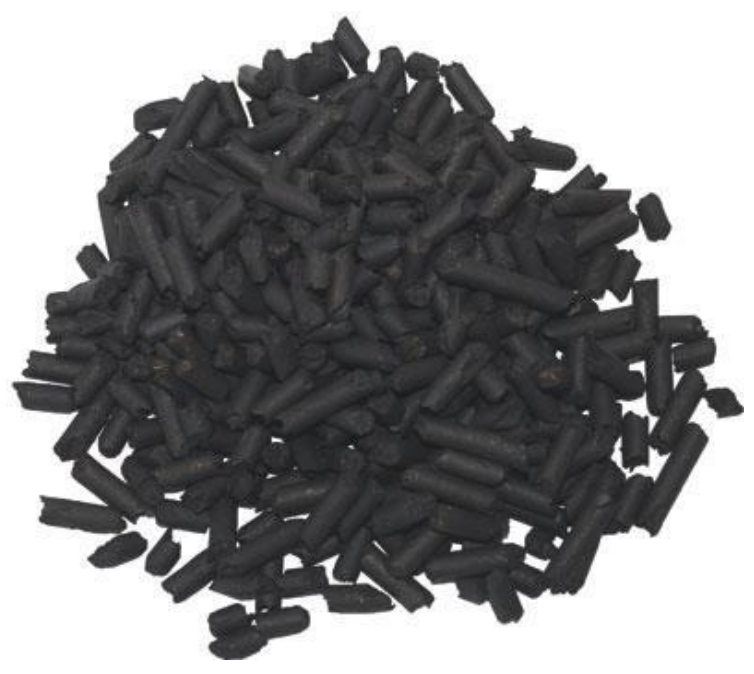

Figure 1 - Torrefied Biomass Pellets [5]

\section{ADVANTAGES OF BIOMASS PYROLYSIS}

During the torrefaction process, the water contained in biomass as well as volatiles are released while the biopolymers (cellulose, hemicelluloses and lignin) partly decompose giving off various types of volatiles. The final product is remaining solid, brittle, blackened material that is referred to as torrefied biomass (biocoal). During the process, the input biomass typically loses $20-30 \%$ of its mass (bone dry basis) and $10 \%$ of its heating value, which is used as a heating fuel for the torrefaction process. Since the torrefied product already loses a certain quantity of volatiles in the course of thermo-chemical treatment, smaller quantity remains after the combustion process. There is little chance to observe fungal growth and microbial activity, given the very dry torrefied biomass [6].

After biomass undergoes torrefaction it can be densified and transformed, usually into briquettes or pellets using conventional densification equipment, to increase its mass and energy density.
The result of the torrefaction process is torrefied biomass with density $240 \mathrm{~kg} / \mathrm{m}^{3}$ and energy value $18,75 \mathrm{MJ} / \mathrm{kg}$, which then undergoes pelletizing and densification to $800 \mathrm{~kg} / \mathrm{m}^{3}$, and energy value is increased to $21,7 \mathrm{MJ} / \mathrm{kg}$ [7]. In addition, torrefaction alters the biomass hydrophilic properties to more hydrophobic ones allowing simple storage procedures and it goes hand-in-hand with a greater resistance against biological degradation, self-ignition and physical decomposition in general. Before the torrefaction process takes place, biomass has to be dry and have a moisture content of less than 20\%. Hydrophobic properties of the product ensure that the fuel is less sensitive to decomposition and absorption of moisture.

After the pyrolisis process, absorption of water and moisture is reduced depending on the degree of pyrolisis. The results of the torrefaction process are torrefied pellets with high quality fuel that is closely similar to charcoal. The increase in heating value is caused by the removal of moisture and some organic compunds from the original biomass. A fundamental difference between the torrefied pellets and charcoal is the difference in volatile matter since in torrefication processes the aim is to maintain volatile matter (and thereby energy) in the fuel as much as possible.

An important role in the internal bonding of the pellets is assigned to lignin. During the pyrolisis process, lignin is partly decomposed, depending on the conditions of the process. For preparation of a compact pellet it is needed to ensure optimal conditions during the pyrolisis process and pelletezing of torrefied biomass at higher temperature or under higher pressure.

\section{TORREFACTION PROCESS SCHEME}

Wood biomass usually contains $80 \%$ volatile matter and $20 \%$ fixed carbon in terms of percentage of dry matter [8]. Reactor process conditions related to wood torrefaction depend on time of storage and flow of a raw material, manner of heat transfer, amount of biomass input, size of a reactor and mechanism of a reactor.

Thermal energy required for drying within the torrefaction process can be obtained:

- by direct or indirect heating with recirculated flue gases,

- by circulation of gas used for heating process,

- by circulation of water vapor from direct or indirect heating process.

Figure 2 shows the main torrefaction process on the basis of heat transfer. In the process input raw material contains $40 \%-50 \%$ moisture. In the torrefaction process, biomass enters the biomass feeding section with worm air and then follows the reactor section where biomass is converted into torrefied 
material and combustible gas and after the end of the heating process torrefied material enters the bottom of the reactor and through the cooling section is transferred to the storage section. In the course of the compression process, the material is crushed to the same size by grinding mills and pelleted as such [10]. The results of the process are energy concentrated pellets that are ready for storage and transport.

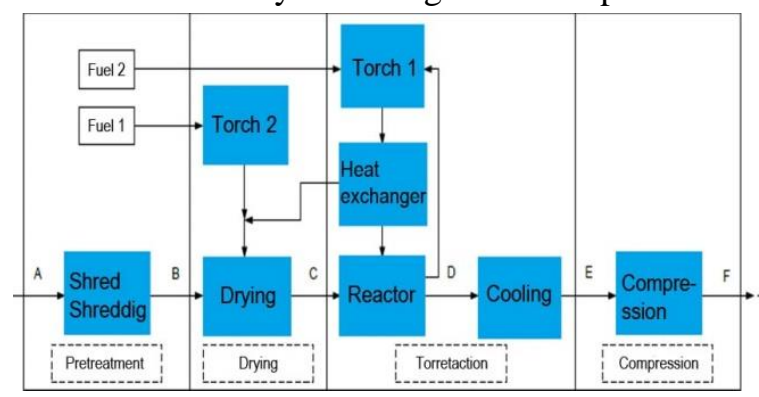

Figure 2 - Torrefaction scheme [9]

\section{TORREFACTION TECHNOLOGY REACTORS}

Technologies applied in the torrefaction process are characterized by different reactor types:

- rotating drum reactor,

- spiral reactor,

- Herreshoff oven or multiple hearth furnace reactor,

- torbed reactor,

- moving bed reactor,

- belt conveyor reactor,

- microwave reactor,

- fluidized bed reactor.

Figure 3 shows a rotating drum reactor.

In the course of torrefaction, biomass is heated directly or indirectly by means of water vapour. The process can be controlled by change of pyrolysis temperature, rotating speed, length and angle of the drum. Rotation of the drum ensures that biomass particles in the reactor are properly mixed with good transfer of heat. In addition, the advantage of this process is reflected in the fact that it can be utilised for treatment of a wide range of biomass particle sizes. Its disadvantages are: poor control of temperature, limited capacity, high costs.

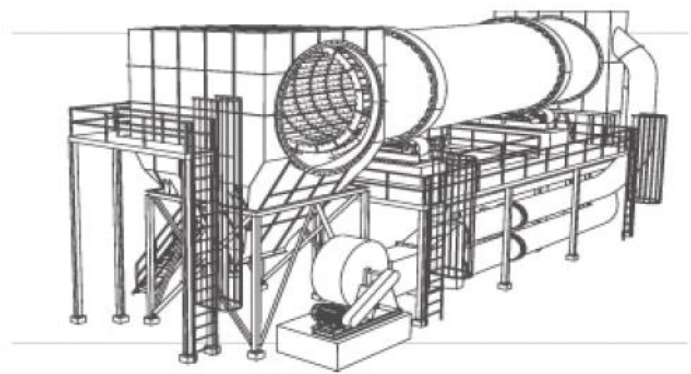

Figure 3 - Rotating drum [8]
Spiral reactor can contain one or more spirals that are used for biomass transfer through the reactor. This type of reactor can be used both vertically and horizontally. Through the hollow wall of a spiral passes heated medium. The advantages of the method are: relatively cheap reactor, better flow of biomass, capability to receive high volume of biomass particles. The spiral reactor is shown in Figure 4. This type of reactor can also contain one or more of the spiral through which is conducted transort biomass. These technologies we can be used in horizontal or vertical format. The spiral is hollow and there goes the warm medium that performs heating biomass.

The disadvantages of the reactor are: uneven torrefaction of biomass, poor heat exchange [11].

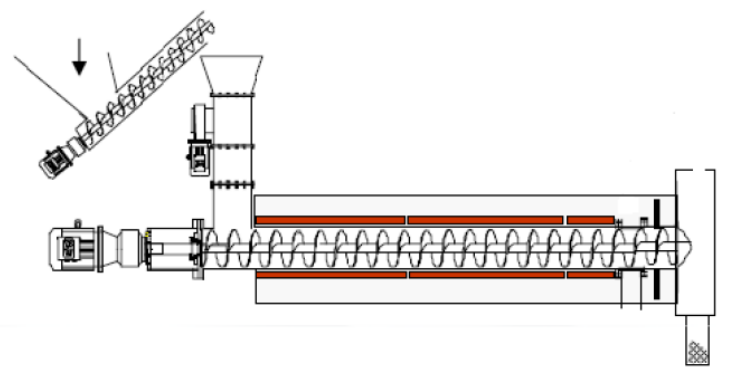

\section{Figure 4 - Spiral reactor [8]}

Multiple hearth furnace reactor (Herreshoff oven) consists of several circular hearths or kilns superimposed on each other and enables use of high volume of biomass particles. The temperature in the reactor gradually increases from $220^{\circ} \mathrm{C}$ to $300{ }^{\circ} \mathrm{C}$. The Herreshoff oven or multiple hearth furnace reactor is shown in Figure 5.

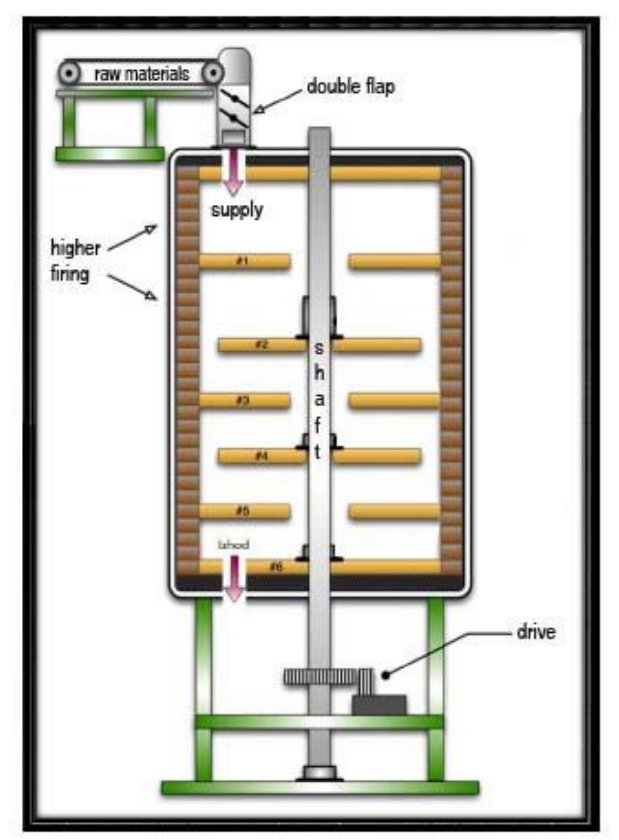

Figure 5 - Herreshoff oven or multiple hearth furnace reactor [8] 
Biomass is fed from the upper side of the reactor into the first hearth and then is swepth into the second hearth and next hearth by action of rotating "rabble arms"; while moving downwards within the reactor, biomass particles are mixed and gradually heated. The process lasts about thirty (30) minutes [8]. The advantages of the process are: good transfer of heat, capability to receive high volume of biomass particles, good control of temperature while disadvantages include large dimensions of the reactor, large consumption of gas for heating [11].

Torbed torrefaction reactor utilises transfer of heat by injection of high velocity gas from the bottom of the reactor $(50 \mathrm{~m} / \mathrm{s}$ to $80 \mathrm{~m} / \mathrm{s})$, through stationary angled blade and as a result the gas lifts and moves the biomass bed vertically and horizontally and quickly makes the particles warm. The Torbed reactor is shown in Figure 6. Intensive transfer of heat enables operation of the reactor under very high temperatures (up to $380^{\circ} \mathrm{C}$ ). The advantages of the method are: short period of retention $(<100 \mathrm{~s})$, fast transfer of heat, large flow due to short retention period and fast transfer of heat, there are no mobile parts in the reactor, its capability to precisely monitor the product, low energy consumption rate. Drawbacks: limited capacity, high temperature leads to increased loss of volatiles [11].

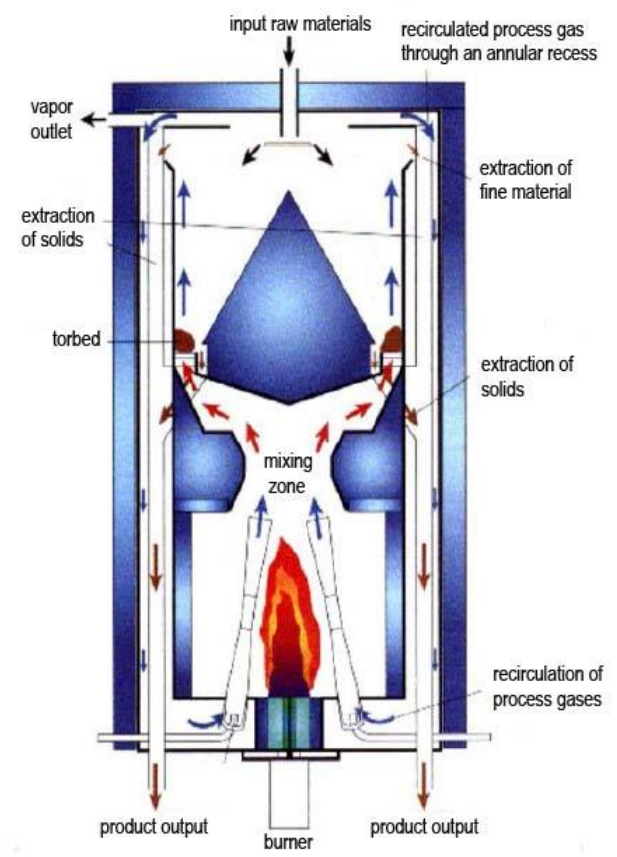

Figure 6 - Torbed reactor [8]

Moving bed torrefaction reactor is composed of a closed reactor, where biomass enters from the top and during the process gradually moves downwards while warm medium arrives from the lower part (Figure 7). This reactor doesn't contain a mechanism for mixture of biomass particles and therefore problems in terms of heat transfer occur, resulting in unevenly torrefied product. Percentage of biomass occupancy in reactor is high compared to torbed procedure since the whole size of the reactor can be utilized in the process. The advantages of the method are: relatively simple and cheap procedure, high capacity of the reactor, no mobile parts. Drawbacks: poor transfer of heat, poor control of temperature [11].

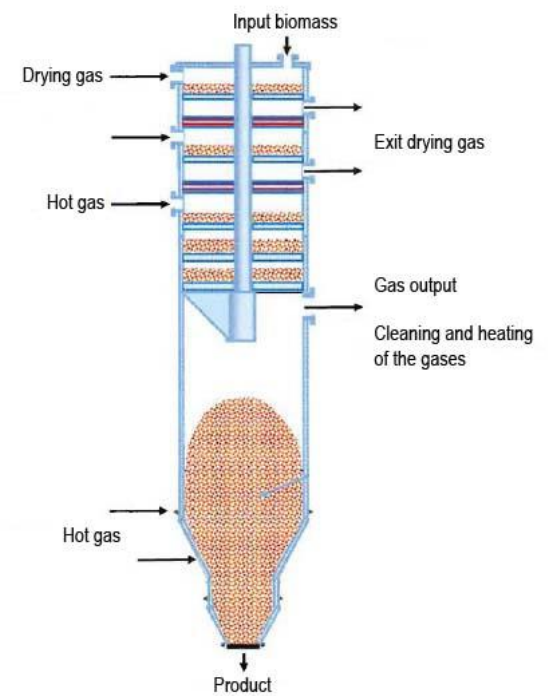

\section{Figure 7 - Moving bed reactor [7]}

Belt conveyor reactor -the raw biomass is fed on stripped perforated belt conveyor into reaction and heating is enabled by hot air injection. Several belt conveyors are oscilated resulting in even thermal distribution and biomass particles fell down from one to another. The speed of belts can be controled. Advantages: better control of temperature, relatively low investment costs. Disadvantages: occlusions caused by small particles can occur because of perforated belt, the system includes a lot of mechanical parts and that increases maintenance costs [11].

Microwave reactor. Alternative option for biomass torrefaction process is microwave reactor. The main barrier to application of this technology is its need to access electric power. Advantages: hight transfer of heat, fast torrefaction process, good control of temperature. Disadvantages: use of electricity [8].

\section{CONCLUSION}

Biocoal attracts immense attention of experts due to increasingly obvious problem pertaining to climate changes caused by carbon dioxide emissions $\left(\mathrm{CO}_{2}\right)$ and gases that create a so called 'greenhouse effect'. Multiple benefits of biocoal utilization shall be visible in future when all necessary conditions for massive application of commercial torrefaction are met. Future efforts need todeal with optimization of the torrefaction and pelletization processes in order to achieve a succesfull commercialization. 


\section{REFERENCES}

[1] Živković, V., Prša, I., Turkilin, H., Sinković, T., Jirous, V., Dimensional stability of heat treated wood floorings, Drvna industrija No. 59(2), pp. 69-73, 2008.

[2] Austin, A. Studyng switchgrass, Biomass Power and Thermal, pp. 46-51, April 2010 (11).

[3] Sinha S, Jhalani A, Ravi M. R, Ray A, Modelling of pyrolysis in wood: A review, SESI Journal, pp. 4162, Vol. 10(1), 2000.

[4] Wilén C, Sipilä K, Tuomi S, Hiltunen I, Lindfors C, Wood torrefaction - market prospects and integration with the forest and energy industry. Espoo, [cited:15.01.2017.] Available: http://www.vtt.fi/inf/pdf/technology/2014/T163.pdf, March 2014.

[5] Heather H, State of the industry. [Internet] July 2015,[Cited:20.01.2017.]Available:http://www.cana dianbiomassmagazine.ca/news/state-of-theindustry2287

[6] Wilén C, Jukola P, Järvinen T, Sipilä K, Verhoeff F, Kiel J, Wood torrefaction -pilot tests and utilisation prospects, Energy research Centre of the Netherlands, Kopijyvä Oy, Kuopio, 2013. [Cited:
25.01.2017.] Available: http://www.vtt.fi/inf/pdf/technology/2013/T122.pdf

[7] Lastnosti bukovega oglja. May 2015, [Cited: 28.01.2017.] Available: https://sites.google.com/site/ogljarskiklub/o-oglju/lastnostibukovega-oglja

[8] Koppejan J, Sokhansanj S, Melin S, Madrali S. Status overview of torrefaction technologies, IEA Bioenergy Task 32 final report, pp. 16-19, December 2012.

[9] Arpiainen V, Wilen C, Production of Solid Sustainable Energy Carriers from Biomass by Means of Torrefaction, Deliverable No. D3.2. Report on optimisation opportunities by integrating torrefaction into existing industries, Available: https://sector-project.eu/fileadmin/downloads/deliverables/SECTOR_D3. 2_VTT_final.pdf, 2013.

[10] Bagramov G. Economy of converting wood to biocoal. Master's thesis, Lappeenranta University of Technology, pp. 45-96, 2010.

[11] Batidzirai B, Mignot A. P. R, Schakel W. B, Junginger H. M, Faaij A. P. C, Biomass torrefaction technology, Techno-economic status and future prospects. Energy, No. 62, pp. 196-214, 2013.

\section{REZIME}

\section{BIOUGALJ - DOBIJEN PROCESOM TOREFAKCIJA BIOMASE}

Torefakcija predstavlja termičko-hemijski tretman biomase pri odsustvu kiseonika na temperturama od 250-300 C. Ovaj proces se može opisati kao blagi oblik pirolize. Tokom procesa torefakcije dolazi do smanjivanja procenta vode sadržane u biomasi kao i do isparavanja dela isparljivih sastojaka, dok se biopolimer (celuloza, hemiceluloza i lignin) delimično razlažu. Tokom ovog postupka osobine biomase se menjaju do tog oblika da se dobija biogorivo boljih karakteristika za sagorevanje i gasifikaciju. Finalni proizvod je preostali tvrd, suv i pocrneo materijal, bio-ugalj, koji ima veću otpornost na biološku degradaciju, samozapaljivanje i fizičko raspadanje. U radu su opisani postupci torefakcije sa prednostima i manama. Rezultat torefakcije i peletizacije biouglja peleti-gorivo visokog kvaliteta, koje ima slične osobine kao kameni ugalj. Povećanje toplotne vrednosti je posledica odstranjivanja vlage $i$ nekih organskih materija iz prvobitne biomase. Osnovna razlika između peleta biouglja i kamenog uglja je u isparljivim materijama, jer je u procesu torefakcije cilj da se sačuvaju isparljive materije.

Ključne reči: biomasa, torefikacija, piroliza, biopolimer 